\title{
Biliary and plasma copper and zinc in pregnant Simmental and Angus cattle
}

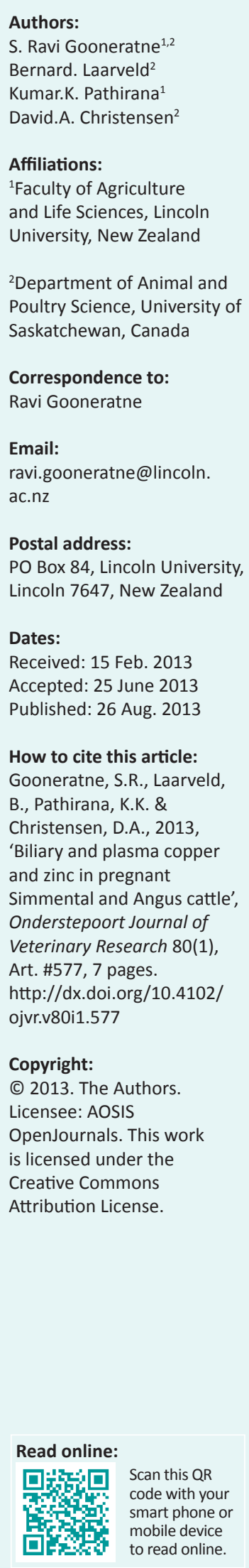

Three each of 3-year-old Angus and Simmental heifers, surgically modified to collect bile, were used to measure the effects of pregnancy and breed on bile flow, biliary copper and zinc excretion and plasma copper and zinc concentrations. Bile copper excretion was significantly higher at 7-mo of pregnancy when samples from both breeds were pooled. From then onwards it declined to its lowest, one week post-partum. During pregnancy, plasma copper concentration increased slightly, reaching its highest level at 7-mo of pregnancy and then decreased slightly until full term. In pooled samples from both breeds, the correlation between increase in bile copper excretion and plasma copper concentration from 0 to 7-mo of pregnancy was high $(r=0.85)$ and significant $(p<0.05)$. Plasma zinc concentration decreased to the lowest level around 6-mo of pregnancy but increased thereafter until full term. In cows that were dried off one week after parturition, major shifts in bile and plasma copper and zinc parameters occurred at one week following and these coincided with a marked decline of bile flow and bile copper and zinc excretion. By 3-mo post-partum, biliary copper and zinc excretion and plasma copper and zinc concentrations had reached levels observed prior to pregnancy. When the data from all samples were pooled, the bile flow and bile copper excretion were significantly $(p<0.05)$ higher in Simmental, and plasma copper and zinc concentration higher in the Angus.

\section{Introduction}

Changes in copper $(\mathrm{Cu})$ and zinc $(\mathrm{Zn})$ metabolism occur during pregnancy to meet the demands of the foetus. Homeostasis of these two essential trace minerals in the pregnant animal depends on the relative absorption, excretion and their transfer to the foetus (Gooneratne, Buckley \& Christensen 1989). High $\mathrm{Cu}$ content in most new-born animals suggests placental transfer and foetal liver storage before birth (Cunningham 1931; Gooneratne 1986; Gooneratne \& Christensen 1989a, 1989b; Hefnawy et al. 2011; Pryor 1964) with foetal liver Cu concentration as high as 50\% in the human foetus (Widdowson 1974). Early work indicated that bile is the major excretory route for many trace minerals (Evans 1973) and $94 \%$ of the excreted $\mathrm{Cu}$ is via faeces (Moss et al. 1974). According to the kinetic modelling of Buckley (1991), $61.4 \%$ of the total $\mathrm{Cu}$ excreted in faeces in non-pregnant cattle is from bile. Since foetal $\mathrm{Cu}$ and $\mathrm{Zn}$ are derived from the blood of the dam, maintaining the concentrations of these two essential trace elements in the maternal plasma during pregnancy, and if possible reducing their excretion, would be of critical importance. Requirements of Simmental are higher than Angus (Mullis, Spears \& McGraw 2003), and Smart and Gudmundson (1980) suggested that Simmental cattle are more susceptible to Cu deficiency than other breeds. More recently, Hansen, Richter and Drewnoski (2010) reported that Angus and Simmental calves exhibit differential trace mineral metabolism, with Simmental showing lower plasma $\mathrm{Cu}$ concentration at $10 \mathrm{~h}$ post-injection of a mineral mix compared to Angus, probably because of increased $\mathrm{Cu}$ excretion via bile in this breed (Gooneratne et al. 1994). Zinc at high concentrations (Bremner, Young \& Mills 1976) can affect $\mathrm{Cu}$ absorption and therefore Cu balance, especially when large doses of Zn salts are given as a treatment for facial eczema (Morris, Amyes \& Hickey 2006). Zinc does not significantly influence the Cu-Mo-S interaction except at very high doses. In the present study (carried out at the Main Barn. Department of Animal and Poultry Science, University of Saskatchewan), the $\mathrm{Cu}$ and $\mathrm{Zn}$ excretion in bile and the plasma $\mathrm{Cu}, \mathrm{Zn}$ concentrations of two breeds of cattle (Angus and Simmental) were investigated during different physiological stages: non-pregnant, pregnant and post-partum.

\section{Materials and methods}

Handling and care of cattle were in accordance with the principles and guidelines established by the Canadian Council on Animal Care (1984). Three each of 3-year-old Angus and Simmental heifers with average body weights of $409 \mathrm{~kg}$ and $431 \mathrm{~kg}$ were surgically modified for collection of bile as described by Symonds, Mather and Hall (1982) 1-mo prior to the experiment. Following surgery, all animals were kept in separate pens and fed Bromegrass hay (Bromus inermis Leyss.) $(60 \%)$, barley $(35 \%)$, canola meal $(3 \%)$ based pelleted ration twice daily to meet National 
Research Council (NRC) (1980) nutrient requirements. The diet contained $40 \mathrm{mg} / \mathrm{kg}, 57 \mathrm{mg} / \mathrm{kg}, 93 \mathrm{mg} / \mathrm{kg}, 42 \mathrm{mg} / \mathrm{kg}$ and $1 \mathrm{mg} / \mathrm{kg}$ of, $\mathrm{Cu}$ (added as copper oxide), $\mathrm{Zn}$, iron (Fe), manganese $(\mathrm{Mn})$ and molybdenum (Mo) respectively, and $0.2 \%$ sulphur (S). The animals were fed $7 \mathrm{~kg}$ of feed daily at the beginning of experiment, increasing weekly by $0.1 \mathrm{~kg}-0.2 \mathrm{~kg}$ to allow for body weight gain, and had free access to drinking water from a municipal source. The higher $\mathrm{Cu}$ level of $40 \mathrm{mg} / \mathrm{kg}$ was recommended by Gooneratne (1986) for pregnant Simmental cattle in Western Canada, which is moderately higher than that recommended by Suttle (2010) for pregnant animals to allow the build-up of a large foetal reserve of $\mathrm{Cu}$. The typical sulphate concentration in the municipal drinking water is $101 \mathrm{mg} / \mathrm{L}$. All animals were synchronised for breeding with prostaglandin, dinoprost trimethamine ('Lutealyse', Upjohn Co.) and artificially inseminated with semen of the respective breed. At one week after parturition, the calves were separated and the cows dried off.

Bile flow, biliary $\mathrm{Cu}$ and $\mathrm{Zn}$ excretion, and plasma $\mathrm{Cu}$ and $\mathrm{Zn}$ concentrations were measured commencing 1 month before pregnancy, monthly during pregnancy, and at 0.25-mo (one week), one, two and three months following parturition. On sampling days, the rate of bile flow was measured by collecting the bile secreted during consecutive 30 min periods between 09:00 and 15:00 each day, into a bag attached to each animal's flank as described by Gooneratne et al. (1994). The volume was measured and $2 \mathrm{~mL}$ removed for analysis whilst returning the remainder into the duodenum through a re-entrant cannula. A blood sample was taken from each animal $30 \mathrm{~min}$ prior to each bile sampling session. $\mathrm{Cu}$ and Zn concentrations in bile and plasma (1:4 dilution) were measured directly by atomic absorption spectrophotometer (Perkin-Elmer, Model 5000, Perkin Elmer Corp., Norwalk, CT, USA) as described by Gooneratne et al. (1994). Overall, $\mathrm{Cu}$ homeostasis is dependent on $\mathrm{Cu}$ absorption, tissue distribution, accumulation in both dam and foetus, and $\mathrm{Cu}$ excretion. Since biliary $\mathrm{Cu}$ excretion is the major route of $\mathrm{Cu}$ excretion, only the $\mathrm{Cu}$ excretion rates (bile $\mathrm{Cu}$ concentration $x$ bile volume) will be presented here.

\section{Statistics}

The data were analysed using the general linear models procedure (Ray 1982). The effect of time of sampling (stage of pregnancy), breed, and pooled samples on the bile $\mathrm{Cu}$ excretion, bile $\mathrm{Zn}$ excretion and plasma $\mathrm{Cu}$ and $\mathrm{Zn}$ concentrations were analysed as a one-way analysis of variance (ANOVA). Next, the effect of time of sampling and breed on the same parameters was analysed as a twoway ANOVA. Parameter means and also means of pooled samples were compared using Duncan's multiple range test (Snedecor \& Cochran 1980). Results were significantly different at $p<0.05$. Regression and correlation analysis between selected parameters were also performed.

\section{Results}

\section{Bile flow}

Overall in pooled data, pregnancy did not significantly affect $(p>0.05)$ the bile flow (Table 1). It declined slightly initially, remained within a narrow range from the second month of pregnancy to full term, but declined markedly at $0.25-\mathrm{mo}$ (one week) following parturition, which was significantly lower $(p<0.05)$ than the flow prior to and at one month of pregnancy. It increased gradually thereafter to reach near initial non-pregnant and early gestation levels by 3-mo postpartum. Overall, mean bile flow in Simmental $(2.60 \mathrm{~L} / 6 \mathrm{~h})$ tended to be greater than that in Angus $(2.12 \mathrm{~L} / 6 \mathrm{~h})$ (Figure 1), and when samples were pooled by breed for the duration of the study, this difference was highly significant $(p<0.01)$. The month $\times$ breed interaction was also significant $(p<0.05)$.

\section{Biliary copper excretion}

Overall, pregnancy did not affect biliary $\mathrm{Cu}$ excretion $(p>0.05)$ (Figure 1). However, there was a tendency in Simmental for the $\mathrm{Cu}$ excretion to gradually increase from 2-mo of pregnancy especially at the end of second trimester and in Angus from the beginning of third trimester. Following parturition, the biliary $\mathrm{Cu}$ excretion declined $(p<0.05)$ to the

TABLE 1: Pooled bile flow, biliary copper and zinc excretion, and plasma copper and zinc concentrations in cattle prior to, during and after parturition.

\begin{tabular}{|c|c|c|c|c|c|c|c|c|c|c|}
\hline \multirow{3}{*}{$\begin{array}{l}\text { Stage of pregnancy } \\
\text { (months) }\end{array}$} & \multicolumn{2}{|c|}{ Bile flow (L/6 h) } & \multicolumn{4}{|c|}{ Bile excretion $(\mathrm{mg} / 6 \mathrm{~h})$} & \multicolumn{4}{|c|}{ Plasma concentration (mg/L) } \\
\hline & \multirow[t]{2}{*}{$M$} & \multirow[t]{2}{*}{ s.e. } & \multicolumn{2}{|c|}{$\mathrm{Cu}$} & \multicolumn{2}{|c|}{$\mathrm{Zn}$} & \multicolumn{2}{|c|}{$\mathrm{Cu}$} & \multicolumn{2}{|c|}{$\mathrm{Zn}$} \\
\hline & & & $M$ & s.e. & $M$ & s.e. & $M$ & s.e. & $M$ & s.e. \\
\hline-1 & $2.74^{\mathrm{a}}$ & 0.25 & $0.37^{a, b}$ & 0.09 & 1.39 & 0.18 & $1.02^{\mathrm{c}}$ & 0.11 & $1.08^{b}$ & 0.09 \\
\hline 1 & $2.86^{\mathrm{a}}$ & 0.24 & $0.40^{\mathrm{a}, \mathrm{b}}$ & 0.09 & 1.53 & 0.24 & $0.99^{c}$ & 0.08 & $1.06^{\mathrm{b}, \mathrm{c}}$ & 0.07 \\
\hline 2 & $2.44^{\mathrm{a}, \mathrm{b}}$ & 0.18 & $0.46^{\mathrm{a}, \mathrm{b}}$ & 0.11 & 1.50 & 0.30 & $1.04^{c}$ & 0.09 & $1.06^{\mathrm{b}, \mathrm{c}}$ & 0.06 \\
\hline 3 & $2.12^{\mathrm{a}, \mathrm{b}}$ & 0.28 & $0.48^{\mathrm{a}, \mathrm{b}}$ & 0.10 & 1.15 & 0.16 & $1.05^{c}$ & 0.10 & $0.94^{\mathrm{b}, \mathrm{c}, \mathrm{d}}$ & 0.04 \\
\hline 4 & $2.34^{\mathrm{a}, \mathrm{b}}$ & 0.21 & $0.56^{a, b}$ & 0.16 & 0.98 & 0.20 & $1.13^{\mathrm{c}}$ & 0.11 & $0.88^{b, c, d}$ & 0.02 \\
\hline 5 & $2.23^{\mathrm{a}, \mathrm{b}}$ & 0.21 & $0.52^{\mathrm{a}, \mathrm{b}}$ & 0.20 & 1.03 & 0.08 & $1.14^{c}$ & 0.06 & $0.85^{b, c, d}$ & 0.05 \\
\hline 6 & $2.25^{\mathrm{a}, \mathrm{b}}$ & 0.31 & $0.60^{\mathrm{a}, \mathrm{b}}$ & 0.24 & 1.23 & 0.20 & $1.26^{\mathrm{b}, \mathrm{c}}$ & 0.08 & $0.73^{d}$ & 0.04 \\
\hline 7 & $2.51^{\mathrm{a}, \mathrm{b}}$ & 0.17 & $0.69^{a}$ & 0.14 & 1.18 & 0.22 & $1.63^{\mathrm{a}}$ & 0.14 & $0.82^{\mathrm{c,d} d}$ & 0.06 \\
\hline 8 & $2.52^{\mathrm{a}, \mathrm{b}}$ & 0.18 & $0.44^{\mathrm{a}, \mathrm{b}}$ & 0.08 & 1.14 & 0.20 & $1.18^{\mathrm{b}, \mathrm{c}}$ & 0.09 & $0.95^{b, c, d}$ & 0.07 \\
\hline 9 & $2.60^{\mathrm{a}, \mathrm{b}}$ & 0.28 & $0.41^{\mathrm{a}, \mathrm{b}}$ & 0.04 & 1.13 & 0.28 & $1.08^{\mathrm{c}}$ & 0.05 & $1.06^{b, c}$ & 0.13 \\
\hline+0.25 & $1.79^{\mathrm{b}}$ & 0.28 & $0.10^{\mathrm{b}}$ & 0.01 & 0.91 & 0.14 & $1.53^{\mathrm{a}, \mathrm{b}}$ & 0.09 & $1.31^{\mathrm{a}}$ & 0.13 \\
\hline+1 & $1.97^{\mathrm{b}}$ & 0.19 & $0.35^{\mathrm{a}, \mathrm{b}}$ & 0.11 & 1.42 & 0.64 & $1.33^{a, b, c}$ & 0.15 & $0.91^{b, c, d}$ & 0.05 \\
\hline+2 & $2.07^{a, b}$ & 0.14 & $0.41^{a, b}$ & 0.19 & 1.54 & 0.17 & $1.22^{\mathrm{b}, \mathrm{c}}$ & 0.17 & $1.08^{b}$ & 0.06 \\
\hline+3 & $2.59^{a, b}$ & 0.31 & $0.43^{a, b}$ & 0.15 & 1.58 & 0.52 & $1.14^{c}$ & 0.12 & $1.05^{\mathrm{b}, \mathrm{c}}$ & 0.09 \\
\hline
\end{tabular}


lowest recorded level at 0.25 -mo at the time the calves were weaned. It then gradually recovered to reach levels similar to non-pregnant and pregnant levels from one to three months post-partum. Overall, mean biliary $\mathrm{Cu}$ excretion was significantly $(p<0.05)$ higher in Simmental $(0.55 \mathrm{mg} / 6 \mathrm{~h})$ than in Angus $(0.34 \mathrm{mg} / 6 \mathrm{~h})$. Biliary $\mathrm{Cu}$ excretion profiles in the two breeds were compiled for analysis (Figure 1). A comparison of bile $\mathrm{Cu}$ excretion in pooled Simmental and Angus samples taken at each month was significantly higher $(p<0.05)$ at the 7 th month of pregnancy compared to the excretion one week after parturition.

\section{Biliary zinc excretion}

Month of sampling showed no effect on biliary $\mathrm{Zn}$ excretion (Figure 2). The biliary $\mathrm{Zn}$ excretion between the breeds was variable throughout pregnancy. In both breeds, it remained within a narrow range, declining slightly in the second trimester, which was most marked in Simmental, and declining again at 0.25-mo (one week) following parturition in both breeds at the time of weaning of calves, compared to the value at 9-mo of pregnancy and then continued to increase from then onwards, with the highest concentration recorded in Angus at 2-mo and in pooled samples at 3-mo after parturition. The month of sampling, breed and month $x$ breed interaction were not significant $(p>0.05)$.

\section{Plasma copper concentration}

The breed- and pooled-plasma $\mathrm{Cu}$ concentrations are shown in Figure 1 and Table 1 respectively. In both breeds, gestation or parturition had no significant effect on plasma $\mathrm{Cu}$ concentration, except for a high concentration at the beginning of the third trimester. When the samples from both breeds were pooled, the plasma concentration was significantly $(p<0.05)$ higher at 7 -mo compared to several other time points. By 8-mo of pregnancy, the concentration declined to early pregnancy concentrations and remained so until parturition. At 0.25-mo (one week) following parturition, plasma $\mathrm{Cu}$ concentration increased compared to the concentration at full term. Then it gradually declined to reach a concentration similar to that prior to conception and early pregnancy. During the experiment, Angus tended to have a higher plasma $\mathrm{Cu}$ concentration compared to Simmental.

\section{Plasma zinc concentration}

The overall mean plasma $\mathrm{Zn}$ concentration between the breeds during the experiment was similar, with a mean of $0.94 \mathrm{mg} / \mathrm{L}$ in Angus vs. $0.97 \mathrm{mg} / \mathrm{L}$ in Simmental. For both breeds, the plasma $\mathrm{Zn}$ concentration remained within narrow limits during early pregnancy, declined during second trimester, gradually increased through the third trimester to full-term to reach the highest overall concentration one week (0.25-mo) post-partum. The plasma $\mathrm{Zn}$ concentration then declined $(p<0.05)$ again from 1-mo post-partum onwards to reach values closer to the non-pregnant and early gestation concentrations. Overall, in pooled samples, plasma $\mathrm{Cu}$ and
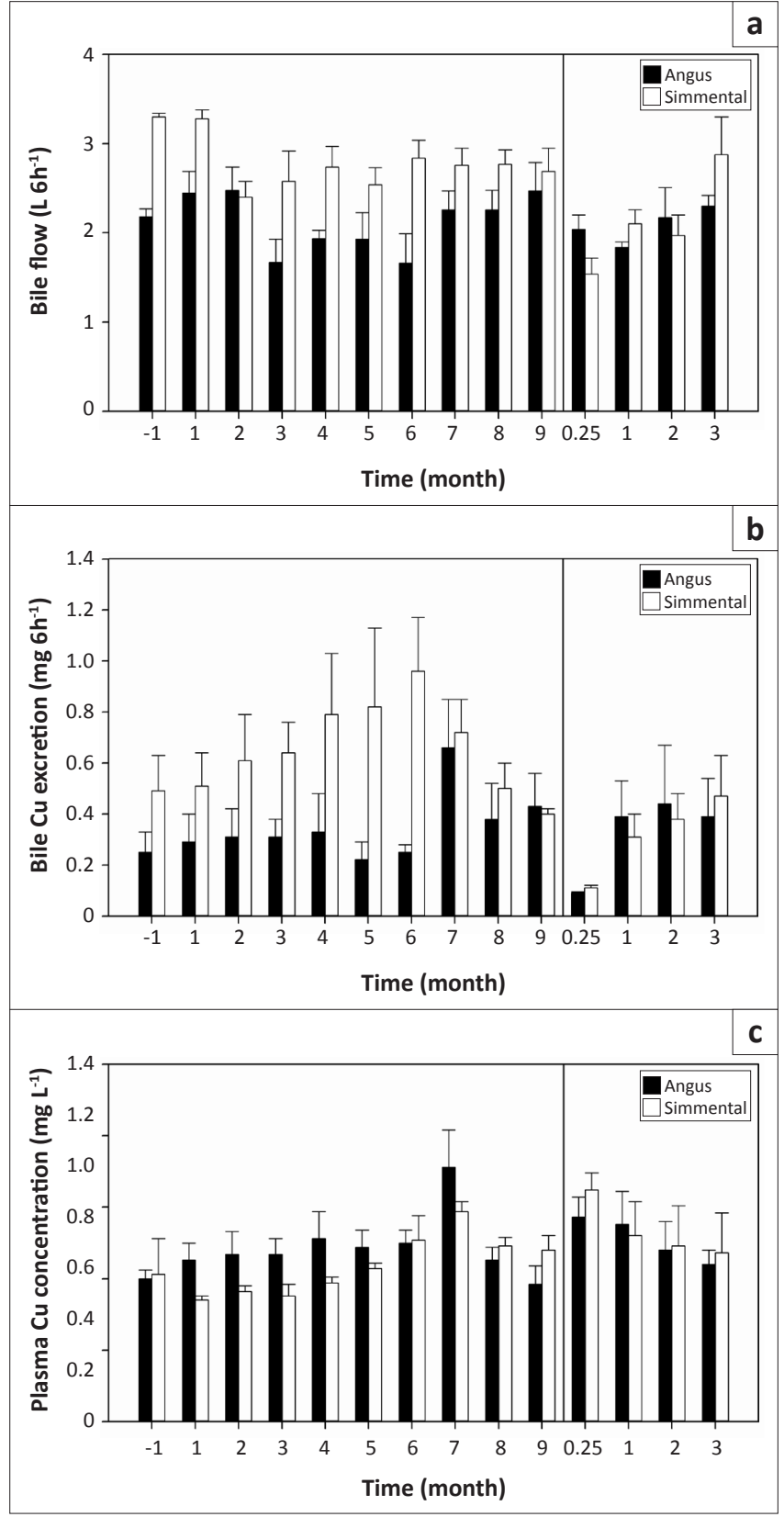

FIGURE 1: Bile flow, bile copper excretion and plasma copper concentration profiles in Simmental and Angus cattle prior to, during and following pregnancy.

Zn concentrations (Table 1; Figure 1 and Figure 2) showed a negative correlation $(r=-0.66)$ until third trimester and a relatively high positive correlation thereafter $(r=0.9)$.

\section{Discussion}

To our knowledge, this is the first report on biliary $\mathrm{Cu}$ and $\mathrm{Zn}$ excretion in cattle prior to, during, and after pregnancy, and it also compares differences in these parameters in two breeds of cattle, Simmental and Angus. The experimental model used in this study was technically challenging. Only a small number of animals could be used because of the care required to maintain bile cannulae and duodenal re-entrant cannulae clean and without blockages for over one year and especially in pregnant animals where displacement of organs can occur during pregnancy. Only the pooled data (Table 1) showed 

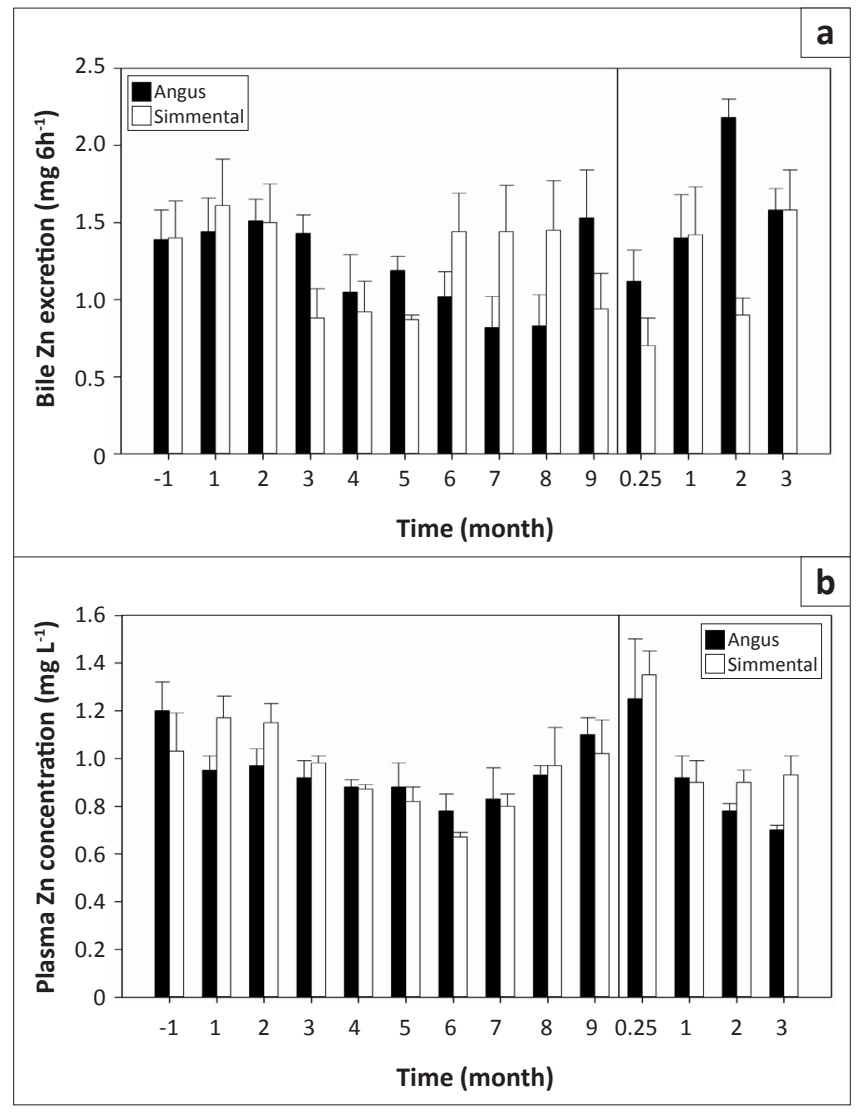

FIGURE 2: Bile zinc excretion and plasma zinc concentration profiles in Simmental and Angus cattle prior to, during and following pregnancy.

statistically significant differences during certain sampling times. Statistical differences between the two breeds were not discernible, except for the significantly higher $(p<0.05)$ biliary $\mathrm{Cu}$ excretion in pooled samples by Simmental than Angus, due to the small number of experimental animals used in the study and the large variation between animals. So, the discussion on effects due to breed differences will be limited to trends.

The plasma $\mathrm{Cu}$ concentration in cattle fed a balanced diet is around $0.9 \mathrm{mg} / \mathrm{L}$, (Simpson, Mills \& Mader 1981) although breed differences exist. The pooled plasma $\mathrm{Cu}$ concentration observed in this study prior to pregnancy and post-partum was mostly above $1 \mathrm{mg} / \mathrm{L}$. However, unlike in other studies, the diet in this study contained $40 \mathrm{mg} \mathrm{Cu} / \mathrm{kg}$, which might seem excessive but is the amount required in cattle in Western Canada to supply the requirements of the foetus without an excessive drain on the dam liver $\mathrm{Cu}$ (Gooneratne, Laarveld \& Christensen, unpublished observations). This is because of the high sulphate in deep well water in the province, although the sulphur concentration in this study was not high. However, in non-pregnant Simmental and Angus cattle on a similar diet as in this study, the plasma $\mathrm{Cu}$ concentration was even higher, $>1.5 \mathrm{mg} / \mathrm{L}$ in both Simmental and Angus (Gooneratne et al. 1994). Copper accretion in bovine foetus and non-foetal conceptus increases markedly and linearly during the third trimester (House \& Bell 1993). Thus, a relatively lower plasma $\mathrm{Cu}$ concentration especially during the last 2-mo of pregnancy observed in this study seems to reflect the drain of $\mathrm{Cu}$ to meet the foetal demand.
Angus compared to Simmental had a slightly higher plasma $\mathrm{Cu}$ concentration, at least up to month seven of gestation and at $0.25-\mathrm{mo}, 2-\mathrm{mo}$ and 3-mo post-parturition in the present study. This is supported by our previous studies (Gooneratne et al. 1994), by Crow et al. (1980), and more recently by Hansen et al. (2010) who showed that Simmental calves exhibited significantly lower plasma $\mathrm{Cu}$ concentrations at $10 \mathrm{~h}$ post-injection of Multimin (a mineral mix of $\mathrm{Cu}, \mathrm{Zn}$, $\mathrm{Mn}$ and selenium) compared to Angus calves, probably due to a greater clearance via bile (Gooneratne et al. 1994) and urine (Gooneratne et al. 2011). The higher dietary $\mathrm{Cu}$ supplementation $(40 \mathrm{mg} / \mathrm{kg})$ in the present study may have narrowed the plasma $\mathrm{Cu}$ concentration gap between the two breeds since $\mathrm{Cu}$ unsupplemented Angus compared to $\mathrm{Cu}$ supplemented Angus heifers show much higher differential plasma $\mathrm{Cu}$ concentrations compared to Simmental heifers when both breeds received the same diet (Ward, Spears \& Gengelbach 1995), probably because Simmental excrete more $\mathrm{Cu}$ in bile than Angus (Gooneratne et al. 1994). These observations provide further evidence to explain the prevalence of $\mathrm{Cu}$ deficiency in Simmental compared to other breeds as observed by Smart (1984). The effect of breed on liver and/or plasma Cu concentration has also been reported for sheep by Woolliams et al. (1982) and for other cattle breeds by Miranda et al. (2006). Evidence for genetic variation of $\mathrm{Cu}$ metabolism in Angus, Simmental, and Charolais (Ward et al. 1995), and Hereford-sired cows and Simmentalsired cows (Smart \& Christensen 1985) have also been reported.

In the foetus, the liver is the main site for $\mathrm{Cu}$ storage in humans (Widdowson 1974). In ruminants, about 40\%-70\% of total body $\mathrm{Cu}$ is in the foetal liver, depending on the diet (Woolliams et al. 1983). Therefore the changes in maternal and foetal liver $\mathrm{Cu}$ concentrations during gestation would help to explain concomitant changes in plasma $\mathrm{Cu}$, since liver and plasma $\mathrm{Cu}$ concentrations in pregnant and parturient cows are closely related (Smart et al. 1986). Whilst dam liver $\mathrm{Cu}$ concentration decreases significantly from trimester one through two to three, foetal liver $\mathrm{Cu}$ concentration increases significantly throughout gestation in cattle (Gooneratne \& Christensen 1989a) and pigs (Richards 1999), but the rate of accumulation in the foetus and depletion in the dam depends on the availability of $\mathrm{Cu}$ from the diet (Gooneratne et al. 1986a). In addition, the weight of the foetal liver increases significantly from about 7-mo gestation, which in combination with the significant increase in liver $\mathrm{Cu}$ concentration at that time results in a substantial increase in the total $\mathrm{Cu}$ accretion in the foetal liver (Graham et al. 1994) at the expense of the maternal pool in cattle (Gooneratne, Laarveld \& Christensen, unpublished observations) and sheep (Hefnawy et al. 2011). If only the liver $\mathrm{Cu}$ concentrations and its accretion at different stages of gestation are considered, quantitative accretion may fail to be detected, particularly at times of rapid foetus and foetal liver growth. Thus Abdelrahman and Kincaid (1993) observed the highest foetal liver $\mathrm{Cu}$ accretion during the third trimester, but the $\mathrm{Cu}$ concentration in the liver was not different from the two previous trimesters because of the rapid foetal liver growth. However, according to Graham 
et al. (1994), there is little variation in the dam liver $\mathrm{Cu}$ concentration with stage of pregnancy, but that depends to a large extent on the dietary $\mathrm{Cu}, \mathrm{Mo}$ and $\mathrm{S}$ concentrations, with high dietary Mo and $\mathrm{S}$ concentrations markedly reducing both the dam and foetal liver $\mathrm{Cu}$ concentration (Gooneratne et al. 1986a).

The sudden surge in plasma Cu concentration at the beginning of the last trimester may have been triggered by a high foetal demand, since the demand for many of the essential trace elements also changes markedly during the terminal stages of foetal development (Mills \& Davies 1979), when most of the foetal growth occurs. The exact time this occurs could not be determined because in this study the samplings were carried out at monthly intervals, although it appears to be around the end of the second trimester or the beginning of third trimester. From the findings of Gooneratne et al. (1986a, 1986b), it appears that $\mathrm{Cu}$ is actively transported across the placenta from the dam to the foetus and that the storage of $\mathrm{Cu}$ by the growing foetus proceeds even when the dam is fed a $\mathrm{Cu}$ deficient diet, at the expense of maternal $\mathrm{Cu}$ reserves. The gradual reduction in plasma $\mathrm{Cu}$ concentration from 7-mo of gestation period and an associated reduction in biliary $\mathrm{Cu}$ excretion may have been due to increased foetal accretion of $\mathrm{Cu}$ and the homeostatic mechanisms of the dam operating to maintain the dam plasma $\mathrm{Cu}$ concentration at a reasonable level and conserve much needed $\mathrm{Cu}$ by minimising losses via bile during this time. At one week following parturition, the increased plasma $\mathrm{Cu}$ concentration in the dam may have been due to the sudden absence of foetal demand and/or to support lactation demands. Thus variations in plasma $\mathrm{Cu}$ concentrations under the present experimental conditions are a reflection of the net result of foetal demand and/or lactation and a lack of it following parturition and drying off of the cows at one week post-partum. Thus, the plasma $\mathrm{Cu}$ concentrations in pregnant cattle observed in this study are in agreement with those reported by Smart et al. (1986) and increased plasma $\mathrm{Cu}$ concentration in dams after calving reported by Gonzalez et al. (1988). However, although the maternal homeostatic adaptations to mineral demands are apparent, a clear interpretation seems difficult without corresponding foetal data and limited data in the literature on mineral excretion in bile prior to, during, and after pregnancy.

The range in bile flow rates observed in this study is consistent with the cattle studies of Symonds, Mather and Hall (1982) and Gooneratne et al. (1994) for non-pregnant cattle. However, during pregnancy there were changes, with a decline or steady bile flow in Simmental and Angus respectively during the 1st trimester, a relatively steady flow in both breeds during the second trimester, an increase during the third trimester, and a significant $(p<0.05)$ decline in pooled samples at one week after parturition compared to the last month of pregnancy, non-pregnant and mo-1 of pregnancy. In non-pregnant cattle, different combinations of dietary $\mathrm{Cu}, \mathrm{S}$ and Mo can create significant effects on biliary flow (Gooneratne et al. 1994) whilst short-term intravenous infusions of $\mathrm{Cu}$ have minimal effect (Charmley \& Symonds 1985). In contrast, the changes in bile flow observed in this study with pregnant cattle were probably a reflection of the demands at different physiological stages - non-pregnant, pregnant, and post partum.

In general, bile flow and biliary excretion of $\mathrm{Cu}$ tended to be higher in Simmental throughout the experimental period with few exceptions, with overall averages of $2.60 \mathrm{~L} / 6 \mathrm{~h}$ and $0.55 \mathrm{mg} / 6 \mathrm{~h}$ for Simmental compared to $2.12 \mathrm{~L} / 6 \mathrm{~h}$ and $0.34 \mathrm{mg} / 6 \mathrm{~h}$ for Angus. Gooneratne et al. (1994) found no significant difference between Simmental and Angus in the flow of bile of non-pregnant heifers, although it was relatively greater in Simmental. According to Mills and Davies (1979), biliary secretions in the dam during late foetal development are rich in $\mathrm{Cu}$, and in the current study it peaked at 6-mo of pregnancy in Simmental and 7-mo in Angus (Figure 1). Plasma Cu concentration also followed a similar pattern, with significantly higher concentrations at the commencement of 6-mo and 7-mo of pregnancy. Thus, in most instances, both biliary $\mathrm{Cu}$ excretion and plasma $\mathrm{Cu}$ concentration increased with advancing gestation up to 6-mo or 7-mo of pregnancy ( $r=0.85)$, but declined thereafter up to full-term and this was most marked in Simmental. At one week following parturition, biliary $\mathrm{Cu}$ excretion declined to a value significantly lower than the highest level observed at 7-mo, whereas plasma $\mathrm{Cu}$ concentration increased. Therefore, following parturition and up to 3-mo post-partum, $\mathrm{Cu}$ excretion in bile and plasma $\mathrm{Cu}$ concentration were again closely but inversely related $(r=-0.9)$. Such correlations emphasise again that, in cattle, bile $\mathrm{Cu}$ excretion and plasma $\mathrm{Cu}$ concentration in the cows whilst closely related to each other, are strongly affected by the physiological stage, foetal demands and a shift in Cu-homeostasis mechanisms to maintain the demands of the foetus whilst attempting to maintain maternal $\mathrm{Cu}$ levels within desirable limits (Gooneratne \& Christensen 1989a; Smart, Christensen \& Shargool 1983). This interaction is even more complex in humans (Gambling, Anderson \& McArdle 2008) because of the high prevalence of Fe deficiency in women during pregnancy. The decline in biliary $\mathrm{Cu}$ excretion post-partum could also be interpreted as a consequence of the drain of $\mathrm{Cu}$ into milk during lactation and the elevation of plasma $\mathrm{Cu}$ as a consequence of mobilisation of $\mathrm{Cu}$ reserves to achieve this and the absence of foetal demand. However, lactation in cows does not raise requirements significantly because of the low Cu content of milk (approximately $2 \mathrm{mg} / \mathrm{L}$; Suttle 2010), although the demand from the dam increases, especially in high producing cows.

Copper and $\mathrm{Zn}$ interactions are well known (Bremner et al. 1976; Grace \& Gooden 1980; Saylor, Morrow \& Leach 1980; Tanabe 1980). However, the present experiment is the first investigation into the relationship of these two minerals in plasma and bile as affected by pregnancy rather than as a function of dietary intake. In pooled samples, plasma $\mathrm{Zn}$ was inversely correlated with bile $\mathrm{Cu}(r=-0.77)$ and plasma $\mathrm{Cu}$ was also negatively, but less closely related to bile $\mathrm{Zn}$ 
$(r=-0.41)$. Liver $\mathrm{Cu}$ concentrations decrease following $\mathrm{Zn}$ injection in goat kids (Tanabe 1980) or feeding supplementary Zn to sheep (Saylor et al. 1980).

It appears that biliary $\mathrm{Cu}$ and $\mathrm{Zn}$, and plasma $\mathrm{Cu}$ and $\mathrm{Zn}$ concentrations behave in a similar manner in both Simmental and Angus, albeit with some differences. In humans, the serum $\mathrm{Cu}$ concentration increases whilst serum $\mathrm{Zn}$ declines in the mother during pregnancy (Widdowson 1974) and plasma $\mathrm{Cu}$ and $\mathrm{Zn}$ concentrations were similar in this study also until the beginning of the third trimester. Thereafter until parturition, plasma $\mathrm{Cu}$ concentration decreased whilst plasma Zn concentration increased. Dufty, Bingley and Cove (1977), Smart et al. (1986) and Gonzalez et al. (1988) have reported similar decreases in plasma $\mathrm{Zn}$ concentration in cows as pregnancy advanced, but only Gonzalez et al. (1988) were able to show an increase in plasma $\mathrm{Zn}$ concentration soon after calving, as observed in this study. However, according to Hansard, Mohammed and Turner (1968), plasma $\mathrm{Zn}$ concentration in pregnant cross-bred heifers remains the same throughout pregnancy. It is possible that the higher $\mathrm{Cu}$ supplementation $(40 \mathrm{mg} / \mathrm{kg})$ used in the current study may have altered the $\mathrm{Zn}$ balance. The plasma $\mathrm{Zn}$ concentration during different stages of pregnancy depends on the species, breed or genetic constitution of the cattle, but more importantly on the overall mineral nutrition balance, including $\mathrm{Cu}$ and $\mathrm{Zn}$ supplementation during the gestation period. Highest plasma $\mathrm{Zn}$ concentration recorded one week after calving was associated with a low biliary excretion of $\mathrm{Zn}$.

Trends which could not be fully explained in this study may be due to one or a combination of the following: (1) small sample size with only three cattle per breed, (2) lack of data on trace element concentrations, including $\mathrm{Cu}$ and Zn in pancreatic secretions (Grace \& Gooden 1980), saliva (Stevenson \& Unsworth 1978) and urine, all of which contribute to the overall $\mathrm{Cu}$ and $\mathrm{Zn}$ excretion, (3) lack of data in the literature on absorption and metabolism, excretion of $\mathrm{Cu}$ and $\mathrm{Zn}$ during pregnancy, and (4) a dearth of information on the other minerals that interact with $\mathrm{Cu}$ and $\mathrm{Zn}$ metabolism in pregnant cattle. Nevertheless, the evidence presented here points to partitioning of $\mathrm{Cu}$ due to an increased foetal demand, especially at the end of the second trimester and during the third trimester, and a marked decrease in both biliary $\mathrm{Cu}$ and $\mathrm{Zn}$ excretion one week postpartum, probably to make available more $\mathrm{Cu}$ and $\mathrm{Zn}$ to increase maternal plasma $\mathrm{Cu}$ and $\mathrm{Zn}$ concentration to support early lactation demand. These findings thus provide further support for higher mineral supplementation during pregnancy and especially from mid-gestation onwards as recommended for sheep, cattle, and deer by Grace and Knowles (2010), and especially during the last trimester of pregnancy although this has led to high liver $\mathrm{Cu}$ concentration in some dairy herds in New Zealand (Grace, Knowles \& Hittman 2010).

\section{Conclusion}

In conclusion, the bile $\mathrm{Cu}$ excretion was significantly $(p<0.05)$ higher at 7-mo pregnancy and lowest one week post- partum in all cattle. In pooled samples from both breeds, the correlation between increase in bile $\mathrm{Cu}$ excretion and plasma $\mathrm{Cu}$ concentration from 0 to 7 -mo of pregnancy was high and significant. Major shifts in bile and plasma $\mathrm{Cu}$ and $\mathrm{Zn}$ parameters occurred at one week following parturition. By 3-mo post-partum, biliary $\mathrm{Cu}$ and $\mathrm{Zn}$ excretion and plasma $\mathrm{Cu}$ and $\mathrm{Zn}$ concentrations had reached levels observed prior to pregnancy. Bile flow and bile $\mathrm{Cu}$ excretion were significantly $(p<0.05)$ higher in Simmental, and plasma $\mathrm{Cu}$ and $\mathrm{Zn}$ concentration higher in the Angus.

\section{Acknowledgements}

The authors thank T. Berryere for care of animals and technical assistance. This work was supported by the Saskatchewan Agriculture Development Fund and Natural Sciences and Engineering Research Council of Canada.

\section{Competing interests}

The authors declare that they have no financial or personal relationship(s) which may have inappropriately influenced them in writing this article.

\section{Authors' contributions}

S.R.G. (Lincoln University) was the project leader, performed most of the experiments, and wrote most of the manuscript. B.L. and D.A.C. (University of Saskatchewan) were responsible for experimental and project design. K.K.P. (Lincoln University) was responsible for data analysis and writing some parts of the manuscript.

\section{References}

Abdelrahman, M.M. \& Kincaid, R.L., 1993, 'Deposition of copper, manganese, zinc and selenium in bovine fetal tissue at different stages of gestation', Journal of Dairy Science 76, 3588-3593. http://dx.doi.org/10.3168/jds.S0022-0302(93)77698-5

Bremner, I., Young, B.W. \& Mills, C.F., 1976, 'Protective effect of zinc supplementation against copper toxicosis in sheep', British Journal of Nutrition 36, 551-561. http:// dx.doi.org/10.1079/BJN19760108, PMid:1009077

Buckley, W.T., 1991, 'A kinetic model of copper metabolism in lactating dairy cows', Canadian Journal of Animal Science 71, 155-166. http://dx.doi.org/10.4141/ cjas91-017

Canadian Council on Animal Care (CCAC), 1984, Guide to the care and use of experimental animals, vol. 2, CCAC, Ottawa, ON.

Charmley, L.L. \& Symonds, H.W., 1985, 'A comparison of the ability of cattle and pigs to clear excess copper from the plasma and excrete copper from the plasma and excrete it in bile', in C.F. Mills, I. Bremner \& J.K. Chesters (eds.), Trace element metabolism in man and animals (TEMA -5), pp. 339-341, Commonwealth Agricultural Bureaux, Slough, Scotland.

Crow, G., Smart, M.E., Stricklin, W.R., Christensen, D.A. \& Janzen, E.D., 1980, 'Breed, age and sex effects on blood plasma copper levels in beef cattle', University of Saskatchewan, Department of Animal and Poultry Science Research Reports, Pub. $411,19-22$.

Cunningham, I.J., 1931, 'Some biochemical and physiological aspects of copper in animal nutrition', Biochemical Journal 25, 1267. PMid:16744690, PMCid:PMC1260753

Dufty, J.H., Bingley, J.B. \& Cove, L.Y., 1977, 'The plasma zinc concentration of nonpregnant, pregnant and parturient Hereford cattle', Australian Veterinary Journal 53, 519-522. http://dx.doi.org/10.1111/j.1751-0813.1977.tb07935.x PMid:612331

Evans, G.W., 1973, 'Copper homeostasis in the mammalian system', Physiology Review 53, 535-570. PMid:4354642

Gambling, L., Anderson, H.S. \& McArdle, H.J., 2008, 'Iron and copper, and their interactions during development', Biochemical Society Transactions 36, 12581261. http://dx.doi.org/10.1042/BST0361258, PMid:19021536

Gonzalez, L.S., Bosch, L.M., Gavin, A.M. \& Celadilla, F.L., 1988, 'Influence of reproductive status on the levels of zinc in the blood of cattle', Veterinari Medicina $5,601-602$. 
Gooneratne, S.R., 1986, 'Copper nutrition of beef cows; Effects of sulfate and molybdenum and species susceptibility' in Proceedings of 7th Western Nutrition molybdenum and species susceptibility', in Proceedings of 7th Wester
Conference, , University of Saskatchewan, Saskatoon, pp. 266-292.

Gooneratne, S.R. \& Christensen, D.A., 1989a, 'A survey of maternal Cu status and fetal tissue copper concentrations in Saskatchewan bovine', Canadian Journal of Animal Science 69, 141-150. http://dx.doi.org/10.4141/cjas89-017

Gooneratne, S.R. \& Christensen, D.A., 1989b, 'Survey of maternal and fetal tissue Zn, $\mathrm{Fe}, \mathrm{Mn}$ and Se concentrations in bovine', Canadian Journal of Animal Science 69, 151-159. http://dx.doi.org/10.4141/cjas89-018

Gooneratne, S.R., Buckley, W.T. \& Christensen, D.A., 1989, 'Review of copper deficiency and metabolism in ruminants', Canadian Journal of Animal Science 69, 819-845. http://dx.doi.org/10.4141/cjas89-096

Gooneratne, S.R., Laarveld, B., Smart, E., Ferguson, J.G., Bailey, J.V. \& Christensen, D.A., 1986a, 'Changes in maternal-fetal liver copper levels in bovine following copper and sulfur supplementation', Canadian Journal of Animal Science 66, 1198-1199.

Gooneratne, S.R., Laarveld, B., Smart, E., Ferguson, J.G., Bailey, J.V. \& Christensen, D.A., 1986b, 'Effect of Cu and S supplementation of pregnant cows on subcellular distribution of $\mathrm{Cu}$ in fetal/calf liver pre- and post-partum', Canadian Journal of Animal Science 67, 1187-1188.

Gooneratne, S.R., Laarveld, B., Pathirana, K.K. \& Christensen, D.A., 2011, 'Effects of dietary $\mathrm{Cu}, \mathrm{Mo}$, and $\mathrm{S}$ on urinary $\mathrm{Cu}$ and $\mathrm{Zn}$ excretion in Simmental and Angus cattle', Research in Veterinary Science 91, e116-e120. http://dx.doi.org/10.1016/j. rvsc.2011.01.024, PMid:21338998

Gooneratne, S.R., Symonds, H.W., Bailey, J.V. \& Christensen, D.A., 1994, 'Effects of dietary copper, molybdenum and sulfur on biliary copper and zinc excretion in Simmental and Angus cattle', Canadian Journal of Animal Science 74, 315-325. http://dx.doi.org/10.4141/cjas94-043

Grace, N.D. \& Knowles, S.O., 2010, 'Copper', in N.D. Grace, S. Knowles \& A. Sykes (eds.), Managing mineral and grazing livestock, 1st edn., pp. 59-88, New Zealand Society of Animal Production (Inc), Hamilton, New Zealand.

Grace, N.D. \& Gooden, J.M., 1980, 'Effect of increasing intakes of Zn, Cu and Mn on their secretion via bile and pancreatic juice and their excretions in faeces and urine in sheep fed lucerne pellets', New Zealand Journal of Agricultural Research 23, 293-298. http://dx.doi.org/10.1080/00288233.1980.10425359

Grace, N.D., Knowles, S.O. \& Hittmann, A.R., 2010, 'High and variable copper status identified amongst dairy herds in the Waikato region by concentration of $\mathrm{Cu}$ in liver sourced from biopsies and cull cows', New Zealand Veterinary Journal 58 130-136. http://dx.doi.org/10.1080/00480169.2010.67514, PMid:20514086

Graham, T.W., Thurmond, M.C., Mohr, F.C., Holmberg, C.A., Anderson, M.L. \& Keen, C.L., 1994, 'Relationships between maternal and fetal liver copper, iron, manganese, and zinc concentrations and fetal development in California Holstein cows', Journal of Veterinary Diagnostic Investigation 6, 77-87. http://dx.doi. org/10.1177/104063879400600114, PMid:8011786

Hansard, S.L., Mohammed, A.S. \& Turner, J.W., 1968, 'Gestation age effects upon maternal-fetal zinc utilization in the bovine', Journal of Animal Science 27, 10971102. PMid:5744261

Hansen, S.L., Richter, E.L. \& Drewnoski, M.E., 2010, 'Angus and Simmental exhibit differential trace mineral metabolism', JAM [Joint Annual Meeting of the Federation of Animal Science Societies (ADSA - PSA - AMPA - CSAS - ASAS)] July 2010, Denver, Colorado, p. 388.

Hefnawy, A.E., Shousha, S.M., Abukora, S.Y. \& Tortora-Perez, J., 2011, 'Effect of gestation and maternal copper on the foetal fluids and tissues of copper concentrations in sheep', Veterinary Research 4, 9-12.

House, W.A. \& Bell, A.W., 1993, 'Mineral accretion in the fetus and adnexa during late gestation in Holstein cows', Journal of Dairy Science 76, 2999-3010. http://dx.doi. org/10.3168/jds.S0022-0302(93)77639-0

Mills, C.F. \& Davies, N.T., 1979, 'Perinatal changes in the absorption of trace elements', in Development of mammalian absorptive processes. Ciba Foundation Series 70 pp. 247-266, Excerpta Medica, Amsterdam.

Miranda, M., Cruz, L.M., Lopez-Alonso, M. \& Benedito, L.L., 2006, 'Variations in liver and blood copper concentrations in young beef cattle raised in north-west Spain associations with breed, sex, age and season', Animal Science 82, 253-258. http:// dx.doi.org/10.1079/ASC200522

Morris, C.A, Amyes, N.C., \& Hickey, S.M., 2006, 'Genetic variation in serum coppe concentration in Angus cattle', Animal Science 82, 799-803. http://dx.doi. org/10.1017/ASC200695
Moss, B.R., Madsen, F., Hansard, S.L. \& Gamble, C.T., 1974, 'Maternal-fetal utilization of copper by sheep, Journal of Animal Science 38, 475-479. PMid:4812298

Mullis, L.A., Spears, J.W. \& McGraw, R.L., 2003, 'Effects of breed (Angus v Simmental) and copper and zinc source on mineral status of steers fed dietary iron', Journal of Animal Science 81, 318-322. PMid:12597403

National Research Council (NRC), 1980, Mineral tolerance of domestic animals, National Academy Press, Washington, DC.

Pryor, W.J., 1964, 'The distribution of copper in bovine and ovine foetuses, with reference to their age and maternal liver copper concentrations', Research in Veterinary Science 5, 123-137.

Richards, M.P., 1999, 'Zinc, copper and iron metabolism during porcine fetal development', Biological Trace Element Research 69, 27-44. http://dx.doi. org/10.1007/BF02783913, PMid:10383097

Ray, A.A., 1982, SAS user's guide: Statistics, SAS Institute, Cary, NC.

Saylor, W.W., Morrow, F.D. \& Leach, R.M., 1980, 'Cu- and Zn-binding proteins in sheep liver and intestine: Effects of dietary levels of the metals', Journal of Nutrition 110, 460-468. PMid:7359217

Simpson, A.M., Mills, C.F. \& Mader, H., 1981, 'Tissue copper retention and loss in young growing cattle', in J. MCC.Howell., J.H. Gawthorne \& C.L. White (eds.) Trace Element Metabolism in Man and Animals (TEMA-4), pp. 133-135, Australian Academy of Sciences, Canberra.

Smart, M.E., 1984, 'A study of factors influencing plasma and liver copper and zinc concentrations in beef cattle', PhD thesis, Department of Animal \& Poultry Science, University of Saskatchewan, Saskatoon, SK.

Smart, M.E. \& Christensen, D.A., 1985, 'The effect of cow's dietary copper intake, sire breed, age on her copper status and that of her fetus in the first ninety days of gestation', Canadian Journal of Comparative Medicine 49, 156-158. PMid:4016582, PMCid:PMC1236140

Smart, M.E., Christensen, D.A. \& Shargool, M., 1983, 'The liver copper (Cu) and zinc $\mathrm{Zn}$ ) concentration of the bovine fetus and its dam during pregnancy', Canadian Journal of Animal Science 63, 1021

Smart, M.E., Cohen, R., Christensen, D.A. \& Williams, C.M., 1986, 'The effects of sulphate removal from the drinking water on the plasma and liver copper and zinc concentrations of beef cows and their calves', Canadian Journal of Animal Science concentrations of beef cows and their calves', Canadian
$66,669-680$. http://dx.doi.org/10.4141/cjas86-074

Smart, M. E., \& Gudmundson, J., 1980, 'Secondary copper deficiency in Simmental calves', California Veterinarian 1, 22.

Snedecor, G.W. \& Cochran, W.G., 1980, Statistical methods, 7th edn., lowa State University Press, Ames, IA.

Stevenson, M.H. \& Unsworth, E.F., 1978, 'Studies on the absorption of calcium, phosphorus, magnesium, copper and zinc by sheep fed on roughage-cereal diets', British Journal of Nutrition 40, 491-495. http://dx.doi.org/10.1079/BJN19780151, PMid:718831

Suttle, N.F., 2010, Mineral nutrition of livestock, 4th edition, CAB International, Oxfordshire, pp. 255-305.

Symonds, H.W., Mather, D.L. \& Hall, E.D., 1982, 'Surgical procedure for modifying the duodenum in cattle to measure bile flow and diurnal variation in biliary manganese, iron, copper, and zinc excretion', Research in Veterinary Science 32, 6-11. PMid:7201153

Tanabe, S., 1980, 'Effect of zincinjection on Zn binding incytosols of several tissues of kids', British Journal of Nutrition 44, 355-360. http://dx.doi.org/10.1079/BJN19800050 British Journal of
PMid:7437417

Ward, J.D., Spears, J.W. \& Gengelbach, G.P., 1995, 'Differences in copper status and copper metabolism amongst Angus, Simmental and Charolais cattle', Journal of Animal Science 73, 571-577. PMid:7601792

Widdowson, E.M., 1974, 'Trace elements in foetal and early postnatal development', Proceeds of the Nutrition Society 33, 275-284. http://dx.doi.org/10.1079/ PNS19740050, PMid:4459970

Woolliams, J.A., Suttle, N.F., Wiener, G., Field, A.C. \& Woolliams, C., 1982, 'The effect of breed of sire on the accumulation of copper in lambs, with particular reference to copper toxicity', Journal of Animal Production 35, 299-307. http://dx.doi. org/10.1017/S0003356100000969

Woolliams, J.A., Suttle, N.F., Wiener, G., Field, A.C. \& Woolliams, C., 1983, 'The long-term accumulation and depletion of copper in the liver of different breeds of sheep fed diets of differing copper content', Journal of Agricultural Science Cambridge 100, 441-449. http://dx.doi.org/10.1017/\$0021859600033608 